\title{
Theatrical Performance of Eastern European Holocaust Figures: Wiener, Korczak, Sylvanus
}

\author{
By Karen Berman*
}

\begin{abstract}
This paper addresses three important, but lesser known, figures of the Holocaust through performance. They will be analyzed in their theatrical representations through the eyes of a theatre director. Through my direction of two productions of the play Dr. Korczak and the Children written by former Nazi turned apologist Erwin Sylvanus and performed by non-Jewish college students at Georgetown University and Georgia College, the unique lens of this post-World War II German play, about Jewish Polish hero Dr. Korczak and the children of his orphanage who were ordered to their deaths in a gas chamber, will be analyzed. My new play The Flights of Jan Wiener uncovers Czech Holocaust hero Jan Wiener in performances by Georgia College students in the Czech Republic. Through directorial dramaturgy, the theatrical performances regarding these three Eastern European Holocaust figures will be addressed in the unique ways they contribute to Holocaust theatricalization.
\end{abstract}

\section{Introduction}

This paper seeks to address theatrical performances on three important, but lesser known, figures of the Holocaust. One is a Czech patriot Jan Wiener, one is a Polish hero Dr. Korczak, and one is a former Nazi sympathizer turned apologist Erwin Sylvanus. They will be analyzed in their theatrical representations through the eyes of a director.

From the perspective of a theatre director at two different university campuses in the United States, the two plays discussed in this paper provided a unique opportunity for the director to educate the college students performing in the plays and the community watching the plays about the important human responsibilities they have in society. Prior to the productions of Dr. Korczak and the Children at both campuses, incidents of religious intolerance occurred on campus that revealed the need to educate the entire community. Dr. Korczak and the Children provided an excellent opportunity to educate both campuses about the Holocaust and to foster understanding. The Flights of Jan Wiener and Dr. Korczak and the Children portray the lives of heroic figures Jan Wiener and Dr. Korczak during a time of intolerance and how an average person can have an impact in the fight for tolerance and understanding. The role of the theatre director in these productions directly affected the educational experience on tolerance and

\footnotetext{
*Theatre Chair, Georgia College and State University, USA.
} 
human responsibility for the performers in the plays as well as the education of the audiences that watched the performances.

\section{Dr. Korczak and the Children}

Through my direction of two productions of the play Dr. Korczak and the Children written in 1957 by former Nazi turned apologist Erwin Sylvanus and performed by non-Jewish college students at Georgetown University in Washington, D.C. and Georgia College, Georgia's designated public liberal arts university in Milledgeville, Georgia, the unique lens of this post-World War II German play will be analyzed. This searing play ${ }^{1}$ tells the true story of Jewish Polish hero Dr. Korczak and his orphanage in the Warsaw ghetto. Dr. Korczak is ordered by a Nazi squad leader to lead the 66 children of the orphanage peacefully to their deaths in a gas chamber. If he does this, the squad leader says Korczak will be saved from their fate. The doctor agrees to lie to the children, but says that he will go with them to their deaths, so long as the squad leader allows the four nurses at the orphanage to survive. The squad leader agrees and the nurses were saved as Dr. Korczak and the children went to their deaths. The play powerfully portrays the doctor's dilemma, the evil of the Nazi belief in order and authority, and reasons that the squad leader became a Nazi.

The playwright Erwin Sylvanus was born in Germany and became a Nazi sympathizer. His writings before and during World War II include Nazi views. As a German soldier in World War II, he was injured and spent a number of years recovering in hospitals and sanitariums where his values changed from those of a Nazi to humanitarian concerns. ${ }^{2}$ According to an article by Kerstin Mueller, his 1957 play "presented Germans with a Nazi character who reminded them that the perpetrators had come out from their midst and were still with them in the present". ${ }^{3}$

The real life Dr. Korczak was born into a middle class Jewish family in Warsaw, Poland and became a doctor in Warsaw, Poland specializing in pediatrics. He became fairly well known with a radio program on children and education. Over the years he served as director of two orphanages where he pioneered unique and progressive approaches to education. He gave the

1. Erwin Sylvanus, "Dr. Korczak and the Children," in Postwar German Theatre, ed. Michael Benedikt and George E Wellwarth (New York: EP Dutton \& Co. Inc., 1968).

2. George Wellwarth, introduction to Postwar German Theatre, ed. Michael Benedikt and George E Wellwarth (New: EP Dutton \& Co. Inc., 1968).

3. Kerstin M Mueller, "Challenging the selectivity of memory in 1950s West Germany: Erwin Sylvanus's Dr. Korczak and the Children," Modern Drama 50, no. 2 (Summer 2007): 233. 
children in his orphanages significant responsibilities and trust and he founded a small newspaper distributed throughout Poland for and by children. His work helped to shape and inspire the United Nations Declaration on the Rights of the Child. Dr. Janusz Korczak and 196 of his orphans died together at Treblinka. ${ }^{4}$ In the play there are only 66 children and one actress portrays all of the children. ${ }^{5}$

Structurally, the script is reminiscent of the work of Italian playwright Luigi Pirandello. The production has the effect of both telling the internal story of one man's life and death in the Holocaust and analyzing the story through "actors" and a narrator who are living in the present. This play within a play device serves as an excellent educational resource for generating discussion. This five character piece is done simply, with little set, highlighting the creativity of the student actors at Georgetown and Georgia College. The play begins with the audience watching the five present day actors as they begin rehearsal with a casual discussion of the roles they may be portraying in the play itself. Ten to fifteen minutes into the play, the actors begin to transform into their characters. During the actual rehearsal process that I conducted before the production opened, the actors prepared by studying photos of World War II and reenacting the pictures. The show is about choices, about hope, and about the ways that theater itself can teach us about how to live.

After the death of Dr. Korczak and the children, the play concludes with the Narrator reciting from the Book of Ezekiel. The words in Hebrew were incorporated into the set as part of a wailing wall with backlit words embedded in the wall. Fragments of the Book of Ezekiel were found in the synagogue at Massada. The scroll and the last lines of the play contain the story of Ezekiel in the boneyard in which God leads the prophet Ezekiel to a valley of dry bones and commands him to prophesy to the valley. As Ezekiel prophesies, God restores the bones to life, promising the resurrected people a return to Israel. Just before reciting from the Book of Ezekiel, the Narrator in Dr. Korczak and the Children says: "Janusz Korczak died here and his children died here with him. He told them that he would lead them through the Red Sea. And Janusz Korczak will keep his word. This is a landscape of death, but I know it is also a landscape of life. For I know that the prophet Ezekiel saw the truth; and what he saw will be fulfilled in us."6

Prior to the productions at both campuses, incidents of religious intolerance occurred that caused concerns about the need to educate the entire community. At Georgetown a large menorah in center campus was

4. Gabriel Eichsteller, "Janusz Korczak - His legacy and its relevance for children's rights today," International Journal of Children's Rights 17 (2009).

5. Sylvanus, "Dr. Korczak and the Children," 155.

6. Ibid., 156. 
knocked down and at Georgia College Easter eggs were found throughout the campus with anti-Semitic notes inside. The play provided an excellent opportunity to educate both campuses about the Holocaust and to foster understanding.

Given that the missions of both universities included promoting diversity, understanding, and social justice, Dr. Korczak and the Children was an excellent opportunity to educate the campuses about the Holocaust and to foster tolerance. Translated from the German by George E. Wellwarth, this play presents the Holocaust through the story of the cruel choices that are thrust upon one man by the Nazi regime. The play is instructive in that it has a narrator commenting on the motivations of the characters from an outside perspective, thereby presenting it from the perspective of persons of all religions and backgrounds. The narrator states early in the play: "We're talking about a man - a man called Janusz Korczak. We're not dealing with any made-up plots here; we're dealing with reality." ${ }^{7}$

From my directing perspective, one particularly powerful scene takes place as the two men are juxtaposed simultaneously preparing for the fateful day, the doctor in prayer and the squad leader with a Nazi salute. As a director, I considered this scene to be the core of the play as it involved the choices we all make and brought the play home to the audience. The scene, in alternating sequences, powerfully portrays the doctor's dilemma, the evil of the Nazi belief in order and authority, and reasons that the squad leader became a Nazi. This in fact was playwright Sylvanus's confession. In my direction of the play, I had equal lighting focus on both actors during the alternating moments so that we could fully see their preparations as they dressed and readied themselves for the collection of children and the march to the trains. Both actors had full focus to add to the effect of the crucial confrontation as they completed their final decision-making process. The scene drives the play to its tragic conclusion.

The reasons that the Nazi gives for his acts and ideology include economic issues. He has placed misguided blame for the economic plight of Germany after the First World War, believing that Nazi policies had helped the economy. In Dr. Korczak and the Children, The Nazi says: "Do you remember what it was like before the Nazis took power, eh? Do you remember those block-long lines of unemployed in every single town, do you remember the hunger and misery ... Nobody talks about that anymore today."8

Aly in his book Hitler's Beneficiaries: Plunder, Race War, and the Nazi Welfare State, states that in Germany, "The immediate effect of the complete dispossession of a group of victims was an increase in supply of consumer

7. Ibid., 119.

8. Ibid., 126. 
goods ... that were in great demand. The sudden availability of goods ... was what stabilized prices." ${ }^{\prime 9}$ This lead to my directorial approach to portray the Nazi character as an average German who believed he was a victim of the economic depression. This resulted in having my actors portraying the Nazi character in my two productions of Dr. Korczak and the Children as a full human being rather than the normal one-dimensional evil Nazi.

\section{Portrayal of a Nazi}

The portrayal of the key Nazi character in the play is not only striking but also troubling and upsetting as he is portrayed as a full human being, a family man with feelings and personal goals. Mueller notes that "Sylvanus not only depicted the suffering of Holocaust victims in his play but also put a face on the Nazi perpetrators."10 Sylvanus' play avoids the pure evil one-dimensional Nazi that we see so often in films. I refused to allow the audience to maintain a comfortable distance from this troubling play. When directing this play, I wanted to make the transformation of the actor in rehearsal into a Nazi especially shocking to the audience.

According to George Wellwarth in his 1968 book Postwar German Theatre, postwar German dramatists like Sylvanus and returning exiles "were horrified by the rapidity with which their countrymen had succeeded in repressing all consciousness of their guilt or in transferring it to the dead."11 Sylvanus understood his own guilt and wrote Dr. Korczak and the Children in Wellwarth's words from Postwar German Theatre "to shock the audience into attention" through "an adaptation of the Pirandellian method."12 The basic structure of the Pirandellian method is the play within a play, the best example of which is Pirandello's classic play Six Characters in Search of an Author.

As a director I believe that both of my productions did shock the audience into attention as my pleasant $21^{\text {st }}$ century casual student turned into a Nazi with chilling effect. A number of years ago I had directed Pirandello's Six Characters in Search of an Author, so I was familiar with both the difficulty and the power of Pirandello's device. The actor that I cast in the Nazi role at Georgetown University was a charming young man who was a gentle soul in real life which made the impact of his transformation into a Nazi that much more effective. For those who knew this student actor well, and even for

9. Gotz Aly, Hitler's Beneficiaries: Plunder, Racial War, and the Nazi Welfare State (New York: Henry Holt and Company, 2005), 199.

10. Mueller, "Challenging the selectivity of memory ...," 236.

11. Wellwarth, introduction to Postwar German Theatre, xvi.

12. Ibid. 
those who did not know him except through his charm in the early "rehearsal" scenes, the change was shocking. At Georgia College I cast in that same role a gifted comedian whose transformation was equally amazing as this pleasant well of humor became the heart of evil which provided quite a surprise for the audience.

Daniel Goldhagan in his 1997 book Hitler's Willing Executioners: Ordinary Germans and the Holocaust, quotes a German police battalion member stating "I would also like to say that it did not at all occur to me that these orders could be unjust. ... I believed the propaganda that all Jews were criminals and subhumans and that they were the cause of Germany's decline after the First World War."13

I felt that it was important to drive home a point that many relatively ordinary Germans participated in some way in the evils of the Holocaust. As Goldhagen concludes at the end of his book Hitler's Willing Executioners: Ordinary Germans and the Holocaust "The inescapable truth is that, regarding Jews, German political culture had evolved to the point where an enormous number of ordinary, representative Germans became - and most of the rest of their fellow Germans were fit to be - Hitler's executioners."14 I believe that my two productions succeeded in making that connection for the audience, that many normal very ordinary Germans participated in the Holocaust. Beyond Dr. Korczak I want to turn our attention to another hero of the Holocaust.

\section{The Flights of Jan Wiener}

My new recent play The Flights of Jan Wiener uncovers Czech Holocaust hero Jan Wiener. The play was performed under my direction by Georgia College students in Prague and at an international theatre festival in Hradec Králové, Czech Republic. Wiener begins his flight at age 20 just after his father and step-mother used poison in his presence to commit suicide to avoid the death camps, motivating Wiener to flee through several countries to escape the Nazis. Landing in England, he joined the Czechoslovak bombing squadron of the Royal Air Force to fight the Nazis. ${ }^{15}$ This Jewish anti-Nazi humanitarian patriot who suffered from Nazi atrocities and who, as an airman, valiantly fought the fascists is worth examining. By doing so, this paper will shed light on the embodiment of real-life characters by the Georgia

13. Daniel Goldhagen, Hitler's Willing Executioner's Ordinary Germans and the Holocaust (New York: Alfred A. Knopf Inc., 1997), 179.

14. Ibid., 454.

15. "Jan Wiener, 90, Czech Jew who fought in British Air Force," boston.com, last modified November 27, 2010, http://goo.gl/7o6hE6. 
College cast as they rehearsed and performed in the Czech Republic. The play depicts the death of Wiener's mother in the Terezin Concentration Camp.

In highlighting Czech hero Jan Wiener, I had multiple goals in mind. First I wanted to write a play that would address the important life of this lesser known figure in Czech history after his death. Second, I wanted to give my perspective to the Czech audience members in performance of the play in the Czech Republic. Third I wanted to educate the American university students who would perform in the play about important moments in Czech history through their development of real-life characters and increase their understanding of the importance of the memory of the Holocaust for their generation. I believe I accomplished all three.

In his book Arthur Miller: A Critical Study, Christopher Bigsby quotes famous American Jewish playwright Arthur Miller stating that "Maybe one's function, a writer's function, in part anyway, is to remember, to be the rememberer."16 As I wrote The Flights of Jan Wiener I felt the need to be the rememberer for the memory of Wiener and for his father and mother who died in the Holocaust. As a director I felt compelled to convey their stories to the audience in a memorable way and to immerse my student actors in the real-life characters. This directorial intention corresponds to Christopher Bigsby's words in his book Remembering and Imagining the Holocaust: The Chain of Memory. There he notes that Anne Frank's "account would contribute the most affecting and accessible approach to the Holocaust."17 Anne Frank's story did resonate with me as a Jewish child growing up in Atlanta. To the extent that my non-Jewish student actors in The Flights of Jan Wiener had any awareness of the Holocaust it was very minimal and primarily about Anne Frank. When I first became Chair of Theatre at Georgia College, the first play we produced was the chamber opera Yours, Anne. Jan Wiener was completely unknown to all of my student actors when we began the rehearsal process, but he was also unknown by most in the US and the Czech Republic. As a director, I introduced the actors to the process of becoming these real-life characters from a time and country they had been completely unfamiliar with before we began our adventure.

16. Christopher Bigsby, Arthur Miller: A Critical Study (Cambridge: Cambridge University Press, 2005), 335.

17. Christopher Bigsby, Remembering and Imagining the Holocaust: The Chain of Memory (Cambridge: Cambridge University Press, 2006), 219. 


\section{Rehearsal Process and Grotowski Ideographs}

I utilized ideographs based on the work of Polish theatre theorist Jerzy Grotowski throughout my production. In Thomas Richards 1995 book At Work with Grotowski on Physical Actions, Grotowski told Richards, "After the system of Stanislavski, came his method of physical actions. Do you think that Stanislavski would have stopped there? No, he died. That is why he stopped. And I simply continued his research."18 I have used Grotowski's methods to great effect in a number of productions and it was particularly effective in The Flights of Jan Wiener. The actors' physical explorations connected them to the material and created many stage pictures for the Czech speaking audiences so that the audience could visualize the action of the play through movement even if they did not understand the English words. Richards notes that Grotowski's "work on physical actions is only the door to entering into the living stream of impulses."19 My actors in The Flights of Jan Wiener freely and enthusiastically opened the door to this exploration. The bodies of the actors became the obstacles Wiener faced as he fled, from barbed wire fences to stones. The actors' bodies also became the bomber plane that Wiener flew against the Nazis.

In our work in The Flights of Jan Wiener we were primarily dealing with moments of great stress for the characters with Jan's flights and fights, his father's suicide, and his mother's death in Terezin. For example, just before his suicide early in the play, Jan's father says: "It is truly too late dear. The Nazi soldiers are all around. No Jew can get out now. It is just a matter of time before they take us to a camp. I can't go there."20 In another example of Jan's continuing struggles, while he is in prison he says: "I will get out of here. You cannot keep me. No one can keep me. I will avenge my mother. And my father."21

Grotowski in his 1968 text Towards a Poor Theatre stated that the human being "at a moment of psychic shock, a moment of terror, of mortal danger or tremendous joy, doesn't behave naturally ... [we are] seeking distillation of signs by eliminating those elements of natural behavior which obscure pure impulses."22 The actors found that the physical actions we developed together through improvisations during the rehearsal process assisted them in their

18. Thomas Richards, At Work with Grotowski on Physical Actions (New York: Routledge, 1995), 105.

19. Ibid., 104.

20. Karen Berman and Paul Accettura, The Flights of Jan Wiener (Milledgeville, GA: Playscript, 2012), 10.

21. Ibid., 13.

22. Jerzy Grotowski, Towards a Poor Theatre (New York: Simon \& Schuster, 1968), $17-18$. 
character development and their relationships with each other and their environment.

The student actors became adept at utilizing these ideographs to convey some key parts of the story without words, making the play accessible to the Czech people. The ideographs - especially the physical recreation of the flights and terror that Wiener and his family had experienced as they tried to escape the Nazis solely through actor movements and reactions without words - told the story. The actors created an ensemble in which they played multiple roles.

A number of the Czech audience members who saw the show in Prague and at an international theatre festival, the Theatre European Regions in Hradec Králové in the Czech Republic, told me after our shows that they truly appreciated learning about this hero that most of them had never heard of before. It gave the Czech audience members a new appreciation of their own history.

\section{Student Reactions}

The students' involvement in the play was a life changing experience for them as they recreated through theatre the heroic journey of Wiener. The visit to Terezin was a profound experience for the students. One student, who played Wiener's stepmother, wrote in her journal: "The Holocaust was such a terrible and senseless tragedy. I'm glad that I went to Terezin because now I feel like I better understand the gravity of this part of history and know now why we must continue to share the stories. Because this or any kind of genocide can never be allowed to happen ever again." The student who played Wiener's father called the visit "very moving and reflective."

The cast and I also had the experience of meeting Wiener's widow, Zuzana, at a restaurant in Prague where she told them about their lives and how honored she was that we were doing this play. She talked about their lives in which they continued to fight the Communist regime in Prague and how they came to the US after his imprisonment by the Communists, and where they both taught at American University in Washington, D.C. He taught history and she taught dance. This was an amazing dramaturgical moment for the students to hear from his widow. The restaurant we met her in was an homage to Jan Wiener, including a dashing photo of him on the wall. She was very generous with her time and told the students wonderful stories about their lives together and about Jan's bravery. She also ended her discussion to them by saying that both she and Jan never had a lot of money but they were happy and always believed in what they did in life without 
regard to money. She advised the students to follow their hearts and "do what you love and you will be happy."

In his 2012 book Staging Holocaust Resistance, Gene Plunka states that drama "is the ideal artistic medium to keep alive the memory of the heroes, martyrs, and rescuers who risked their lives to maintain their moral or religious values at a time when saving others meant death."23 The life of Jan Wiener and his mother who died in Terezin and his father who committed suicide rather than go to a concentration camp were important parts of the education of my student actors. For the Czech audience members who were primarily born after the events depicted in the play, this moment of Czech history held significant educational impact. A somber part of Czech history is that the Allied forces gave permission to take parts of Czechoslovakia without a fight at the beginning of World War II.

Gene Plunka ended his 2012 book, Staging Holocaust Resistance by stating "Playwrights need to research the historical and biographical information and then write plays about these noble role models in order to keep alive the memories of those who sacrificed themselves to make the world a better place." 24 The audience and my student actors were profoundly moved as we recreated these real life events. I directed and choreographed the scene of the tragic death of Wiener's mother through dance.

Both Dr. Korczak and the Children and The Flights of Jan Wiener tell their important historical lessons of the Holocaust through the central story of a hero, educating students, Czech audiences, and American audiences about events they know little about.

\section{Other Educational Experiences}

Holocaust theatre productions can also be a springboard for other educational collaborations between university departments and outside organizations and individuals. For example, when our theatre department collaborated with our musical department to present the chamber opera Yours, Anne, about the life of Anne Frank, the production took on a larger purpose. I created around the production a "Symposium on Holocaust Theatre: Staging Justice and Diversity in Our Global World." This symposium was an interdisciplinary 14 event series that brought to campus numerous talk back guest speakers, including three Holocaust survivors. We received

23. Gene Plunka, Staging Holocaust Resistance (New York: Palgrave Macmillan, 2012), 210.

24. Ibid. 
assistance in arranging for the visits by Holocaust survivors from the William Breman Jewish Heritage Museum in Atlanta, Georgia.

For Yours, Anne we brought in a Rabbi from Macon, Georgia and a prominent Methodist minister in Milledgeville, Georgia to conduct an interdenominational discussion about the issues of the play. We also received the assistance of the Consulate General of Israel to the Southeast United States to present a photo exhibit on Bergen-Belsen in collaboration with the Art Department. A particularly rewarding event was our weekday matinee for several hundred community high school students that was called "Lunch and learn." After seeing the play the high school students heard from Holocaust survivor Andre Kessler, followed by an exciting mural drawing session with Georgia College Art Professor Valerie Aranda. The students painted their responses to the play and the Holocaust survivor, which created a powerful mural.

\section{Conclusions}

I found that utilizing theatre to convey important messages and remembrance of the Holocaust was very rewarding and effective with today's university students. As actors in the plays and as audience members, the students responded to the issues far better than a lecture or reading a history book. Making history real to our current generation of students is vital. The lives of Dr. Korczak and Jan Wiener are set before the students in a compelling dramatic form where the story of the Holocaust becomes a story of individual human beings with whom students can identify.

I was again reminded of the importance of all of our work in keeping alive remembrance of the Holocaust when I discussed with our tour guide in Terezin how he was able to conduct these tours day after day. He said that it was important work to remember what happened at Terezin so that it would never happen again. He said he was especially pleased to see my American college students since he said their generation needed to know since there would soon be very few personal witnesses to the tragedy. These theatrical performances of real and little known heroes of the Holocaust provide an important means of keeping alive history for a new generation.

The theatre director has a professional (artistic) and social responsibility to the actors and the audience. Theatre is a medium which can be used to promote social justice. In the productions of Dr. Korczak and the Children and The Flights of Jan Wiener the director must respect the history and historical figures in artistic interpretation. The improvisational techniques used in the rehearsal process assisted in the student actors' respect for and embodiment of these real life characters in a tragic moment of history. The powerful 
portrayal of the lives of these important, but lesser known, heroes of the Holocaust thus provided vital lessons of tolerance and understanding for today's audiences.

\section{Acknowledgments}

Thanks to "Athens Institute for Education and Research" for allowing me to modify templates they had developed.

\section{Bibliography}

Aly, Gotz. Hitler's Beneficiaries: Plunder, Racial War, and the Nazi Welfare State. New York: Henry Holt and Company, 2005.

Berman, Karen. and Accettura, Paul. The Flights of Jan Wiener. Milledgeville, GA: Playscript, 2012.

Bigsby, Christopher. Remembering and Imagining the Holocaust: The Chain of Memory. Cambridge: Cambridge University Press, 2006.

Bigsby, Christopher. Arthur Miller: A Critical Study. Cambridge: Cambridge University Press, 2005.

Eichsteller, Gabriel. "Janusz Korczak - His legacy and its relevance for children's rights today." International Journal of Children's Rights 17, (2009): 377-391.

Goldhagen, Daniel. Hitler's Willing Executioner's Ordinary Germans and the Holocaust. New York: Alfred A. Knopf Inc., 1997.

Grotowski, Jerzy. Towards a Poor Theatre. New York: Simon \& Schuster, 1968.

"Jan Wiener, 90, Czech Jew who fought in British Air Force." boston.com. last modified November 27, 2010. http://goo.gl/7o6hE6.

Mueller, Kerstin M. "Challenging the selectivity of memory in 1950s West Germany: Erwin Sylvanus's Dr. Korczak and the Children." Modern Drama 50, no. 2 (Summer 2007): 233-257.

Plunka, Gene. Staging Holocaust Resistance. New York: Palgrave Macmillan, 2012.

Richards, Thomas. At Work with Grotowski on Physical Actions. New York: Routledge, 1995.

Sylvanus, Erwin. "Dr. Korczak and the Children." In Postwar German Theatre, edited by M Benedikt and GE Wellwarth, 115-157. New York: EP Dutton \& Co. Inc., 1968.

Wellwarth, George. Introduction to Postwar German Theatre, Edited by M Benedikt and GE Wellwarth. New York: EP Dutton \& Co. Inc., 1968. 